\title{
Status of Tuna Resources in the Zambales Coast
}

\author{
Romina V. Yutuc ${ }^{1, *}$, Jenelyn Y. Vallejo ${ }^{1}$, Rachelle A. Mendoza ${ }^{1}$ \\ Bureau of Fisheries and Aquatic Resources - Regional Office 3 \\ Government Center, Maimpis, City of San Fernando, Pampanga, Philippines
}

\begin{abstract}
A B S T R A C T
This study aimed to generate and assess the 10-year (2003-2012) data on estimated annual yield of tuna, the catch per unit effort (CPUE) of dominant fishing gears, catch composition, seasonality, and size composition of tuna species in Zambales Coast. This is in support to the implementation of the National Tuna Management Plan. Results were based on the landed catch recorded at the identified sampling site in major fish landing centers in Zambales. The tuna catch in Zambales showed an increasing trend from 2005 to 2011, the highest catch was observed in 2011 with 12,968 MT. The major tuna fishing gears observed in the area were purse seine, multiple handline, and ring net. The CPUE of the three dominant tuna fishing gears showed that purse seine, a commercial fishing gear, has the highest average CPUE with 1,678.52 kg/day, followed by ring net with $222.07 \mathrm{~kg} / \mathrm{day}$, and multiple handline, which is a municipal fishing gear, with $62.94 \mathrm{~kg} / \mathrm{day}$. There were eight species of tuna being caught in Zambales Coast. The most dominant species caught were skipjack tuna (Katsuwonus pelamis), followed by yellowfin tuna (Thunnus albacares), and bigeye tuna (Thunnus obesus). The monthly seasonal distribution of the three dominant tuna species was also assessed. Peak in the catch of Katsuwonus pelamis was recorded in the first quarter of the year. For Thunnus albacares, the highest catch was observed during the second and third quarter. The bulk of catch for Thunnus obesus appeared on every first and second quarter of the year. All of these species were observed to have almost consistent production in the remaining quarters of every year. Data on size composition of tuna revealed that most of the tuna species landed in Zambales were caught before they reach the length at first maturity. Among species caught, Thunnus albacares and Thunnus obesus recorded the highest percentage of small tuna.
\end{abstract}

^E-mail: rs_vergara@yahoo.com

Keywords: tuna,

Received: 14 May 2017

Accepted: 5 October 2017

purse seine, multiple handline, ring net, catch per unit effort (CPUE)

\section{IN T ROD UCT I ON}

$\mathbf{T}$ he Philippines is situated in a region that boasts with rich marine biodiversity and recognized as one of the top tuna producing countries in the world particularly in the Western and Central Pacific Ocean (WCPO) (WPCFC 2012). The major production areas in the Philippine waters are the Moro Gulf/Celebes Sea, Sulu Sea, South China Sea (Vera 2007), and Southern Luzon (Barut 2002).

Zambales Coast, which is part of the West Philippine Sea, is an important marine fishing ground for pelagic fisheries resources in the province. It has a narrow coastline of more than $110 \mathrm{~km}$ and lies on the northwestern part of the region. The whole municipal coast is generally deep with 900 meters as the deepest part. The bottom is generally characterized as sandy and muddy.

The coastal habitats of the Zambales Province include reefs, seagrass beds, and mangrove forests, which provide shelter to various finfishes and aquatic invertebrates. The average annual municipal and commercial production from 2003 to 2012 of the province was recorded at 12,694 MT (BAS 2003-2012). This figure represents $69 \%$ of the total fisheries production of the province. Tuna and tuna-like species comprised the bulk of this production with $50 \%$ contribution. Ten out of the 11 coastal municipalities of Zambales have tuna unloadings.

Despite its importance to the local economy, data on tuna resources of the whole Zambales Coast is limited. This study aims to document tuna resources - tuna catches, catch per unit effort (CPUE), species composition, seasonality, and size composition, which are used as the basis for fisheries management strategies and policies in the Zambales Coast.

This study, which is also anchored on the National Tuna Management Plan of the Philippines aims to contribute to the generation and analysis of data that would support management decisions for the rational use and conservation of tuna fisheries in the country

\section{METHODOLOG Y}

\section{Data Collection}

Data collection in the study area was conducted from 2003-2012 by trained NSAP enumerators. Six major 
Table 1. Types of Commercial Tuna Fishing Gears in Zambales, 2003-2012

\begin{tabular}{lcccccc}
\hline \multirow{2}{*}{ Fishing Gear } & \multicolumn{4}{c}{ Municipality } & \multirow{2}{*}{ Total } & \multirow{2}{*}{ \% Share } \\
\cline { 2 - 5 } & Subic & Masinloc & Sta. Cruz & & \\
\hline Purse Seine & 4 & 9 & 7 & 20 & 71.4 \\
\hline Ringnet & 1 & 1 & 1 & 3 & 10.7 \\
\hline Danish Seine & 5 & & & & 5 & 17.9 \\
\hline Total & $\mathbf{1 0}$ & $\mathbf{1 0}$ & $\mathbf{8}$ & $\mathbf{2 8}$ & $\mathbf{1 0 0 . 0}$ \\
\hline
\end{tabular}

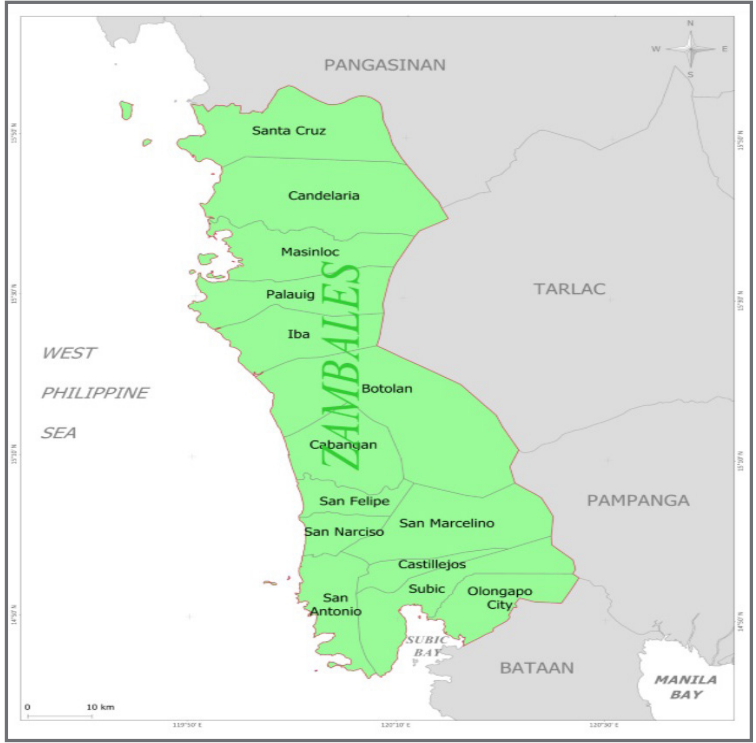

Figure 1. Map of Zambales

fish landing sites located in Subic, Masinloc, and Sta. Cruz were established as sampling stations. Four out of these six stations ( 1 in Subic, 2 in Masinloc, and 1 in Sta. Cruz) were classified as commercial. The fish landing center in Subic has both commercial and municipal fisheries unloadings. Figure 1 shows the established fish landing sites for the National Stock Assessment Program in Central Luzon. These sites were monitored every other two days including Saturdays, Sunday, and holidays. Sampling time varies in every landing center depending on the landing time of fishing boats. The assigned enumerators gathered information on the total number of fishing boats landed during the sampling day, the volume of catch by gear type, species composition, and length measurements of tuna species. Data gathered were summarized monthly and tabulated by species composition and gear type. Fishing boats that were not sampled were also recorded by gear type to obtain the total number of fishing boats landed for a particular sampling day. The data gathered on the total catch from the sampled fishing boats was raised to the total number of fishing boats landed to determine the total catch for the day. The data utilized in this study were landed catch collected from six monitored sampling sites in Zambales.

\section{Gear Inventory}

The data on the inventory of fishing gear was taken by field enumerators from the monitored landing sites. Additional information was also gathered from the gear registry of the Leasing and Licensing Section of BFAR 3 for the commercial fisheries and from the Office of the Municipal Agriculturist for municipal fisheries.

\section{Size Composition}

The data on the catch composition from the sampled fishing boats for each gear were sorted by species. Tuna species were measured in fork length (FL). All measurements were recorded in centimeters.

For the size composition data sampling, the dominant and abundant tuna species were tallied monthly to get the common sizes of the dominant tuna species usually caught in the study area.

\section{Catch, Effort and CPUE}

The catch is recorded as whole weight in kilograms. For this study, the catch per unit effort (CPUE) of the major fishing gears used to catch tuna was determined by taking the quotient of the catch (in $\mathrm{kg}$ ) over the total number of fishing days. The CPUE was computed using raised data. The standardized unit of effort used is kilogram per day (kg/day).

\section{RESULTS AND DISCUSSIONS}

\section{Tuna Fishing Gears Observed in Zambales}

Three types of commercial fishing gears are used in Zambales (Table 1). Purse Seine has the highest percentage share with $71.43 \%$ and is concentrated in Masinloc and Sta. Cruz, Zambales. Danish Seine contributed $17.86 \%$ and was recorded only in Subic, Zambales. Ringnet accounted for $10.71 \%$ and was distributed in the three municipalities of the province.

There are seven types of tuna fishing gears used by municipal fishermen of Zambales (Table 2). A total of 673 fishing gears were recorded in three municipalities with monitored landing sites. Out of the seven types of fishing gears, only two types dominated the list. Multiple Handline has recorded the highest number of 342 gears $(50.82 \%)$ in Subic, Zambales while Handline placed second in terms of number with 234 gears and was recorded in Subic, Masinloc, and Sta. Cruz, Zambales.

\section{Tuna Catch}

Table 3 shows the annual landed catch of tuna species caught by different fishing gears in Zambales. A 
Table 2. Types of Municipal Tuna Fishing Gears in Zambales, 2003-2012

\begin{tabular}{lccccc}
\hline \multirow{2}{*}{ Fishing Gear } & \multicolumn{3}{c}{ Municipality } & \multirow{2}{*}{ Total } & \multirow{2}{*}{ \% Share } \\
\cline { 2 - 4 } & Subic & Masinloc & Sta. Cruz & & \\
\hline Multiple Handline & 342 & & & $\mathbf{3 4 2}$ & $\mathbf{5 0 . 8}$ \\
\hline Handline & 147 & 74 & 13 & $\mathbf{2 3 4}$ & $\mathbf{3 4 . 8}$ \\
\hline Trammel Net & 12 & & & $\mathbf{1 2}$ & $\mathbf{1 . 8}$ \\
\hline Bagnet & 20 & & & $\mathbf{2 0}$ & $\mathbf{3 . 0}$ \\
\hline Bottom Set Longline & 10 & & & $\mathbf{1 0}$ & $\mathbf{1 . 5}$ \\
\hline Otter Trawl & 5 & & & $\mathbf{5}$ & $\mathbf{0 . 7}$ \\
\hline Gillnet & 15 & & 35 & $\mathbf{5 0}$ & $\mathbf{7 . 4}$ \\
\hline Total & $\mathbf{5 5 1}$ & $\mathbf{7 4}$ & $\mathbf{4 8}$ & $\mathbf{6 7 3}$ & $\mathbf{1 0 0 . 0}$ \\
\hline
\end{tabular}

Table 3. Tuna Catch (MT) in Zambales, 2003-2012

\begin{tabular}{|c|c|c|c|c|c|c|c|c|c|c|c|c|}
\hline \multirow{2}{*}{$\begin{array}{c}\text { Fishing } \\
\text { Gear }\end{array}$} & \multicolumn{12}{|c|}{ Year } \\
\hline & 2003 & 2004 & 2005 & 2006 & 2007 & 2008 & 2009 & 2010 & 2011 & 2012 & Total & $\%$ Share \\
\hline Bagnet & 4.97 & 11.65 & 36.94 & 1.64 & 4.25 & 29.96 & .44 & 4.73 & & & 94.59 & 0.14 \\
\hline $\begin{array}{l}\text { Bottom Set } \\
\text { Longline }\end{array}$ & & & & & 2.59 & & 2.02 & 8.81 & 0.25 & .54 & 14.20 & 0.02 \\
\hline $\begin{array}{l}\text { Danish } \\
\text { Seine }\end{array}$ & & 5.15 & 3.36 & & & & & & & & 8.15 & 0.01 \\
\hline Gillnet & 0.83 & & 1.17 & & & & 1.86 & 1.00 & & & 4.86 & 0.01 \\
\hline Handline & 63.21 & 49.11 & 55.44 & 37.38 & 33.83 & 48.24 & 49.35 & 61.29 & 173.67 & 325.21 & 896.73 & 1.33 \\
\hline $\begin{array}{l}\text { Multiple } \\
\text { Handline }\end{array}$ & $1,648.36$ & $1,422.85$ & 522.18 & $1,465.60$ & $1,603.72$ & $1,361.93$ & $1,808.45$ & $2,205.79$ & $1,972.83$ & $1,805.02$ & $15,816.72$ & 23.48 \\
\hline Otter Trawl & 6.02 & & & & & & & & & & 6.02 & 0.01 \\
\hline Purse Seine & $1,099.11$ & $1,369.04$ & $1,904.64$ & $2,725.02$ & $4,627.34$ & \begin{tabular}{|l|}
$5,988.73$ \\
\end{tabular} & $6,445.00$ & $6,410.19$ & $10,672.13$ & $7,150.65$ & \begin{tabular}{|l|l|}
$48,391.86$ \\
\end{tabular} & 71.84 \\
\hline Ringnet & 71.12 & 406.17 & 272.29 & 399.56 & 100.12 & 132.79 & 150.01 & 182.93 & 126.10 & 68.76 & $1,909.83$ & 2.84 \\
\hline $\begin{array}{l}\text { Trammel } \\
\text { Net }\end{array}$ & 14.97 & 1.63 & 1.26 & 4.63 & 36.31 & 42.83 & 32.09 & 38.97 & 23.11 & 17.33 & 213.13 & 0.32 \\
\hline Total & $2,908.60$ & $3,265.61$ & $2,797.27$ & $4,633.82$ & 6,408.15 & $7,604.49$ & $8,489.22$ & \begin{tabular}{|l|}
8913.71 \\
\end{tabular} & \begin{tabular}{|l|}
$12,968.09$ \\
\end{tabular} & $9,367.51$ & $67,356.47$ & \\
\hline \% Share & 4.32 & 4.85 & 4.15 & 6.88 & 9.51 & 11.29 & 12.60 & 13.23 & 19.25 & 13.91 & & 100 \\
\hline
\end{tabular}

total of $67,356.47$ metric tons of tuna was recorded in Zambales for ten year period (2003-2012). There were ten types of fishing gears used for catching tuna in Zambales. Purse Seine dominated the catch with $71.84 \%$ share of total landed production $(48,391.86 \mathrm{MT})$ followed by Multiple Handline and Ringnet with $23.48 \%(15,816.72$ MT) and $2.84 \%$ (1,909.83 MT), respectively. These gears operate either within or near the Fish Aggregating Device (FAD) locally known as "payao". The observed three dominant tuna fishing gears in Zambales was similar to the ones reported in Philippine Fisheries Profile; the use of Purse Seine, ring net, and handline usually accounts for over $75 \%$ of the annual national tuna catch (BFAR \& WCPFC 2012).

Results of the study indicate that tuna resources were primarily caught both in municipal and commercial fishing activity. There were seven types of fishing gears used for municipal fishing and three types of gears for commercial fishing. Tuna catch from commercial fisheries contributed $75 \%$ to the total provincial tuna catch and the remaining 25\% was attributed to municipal fisheries (Figure 2).

Based on the record, there is an increasing trend in the catch of tuna in Zambales for 2005 to 2011 (Figure 3). Highest catch was recorded in 2011 with 12,968.09 MT. The result of the trend on tuna catch is comparable with the report of BAS on 2003-2012. Increase in the catch can be attributed to the unloading of catches of the other fishing vessels from nearby provinces and the addition of two landing centers in Sta. Cruz, Zambales as sampling stations in line with the implementation of the National

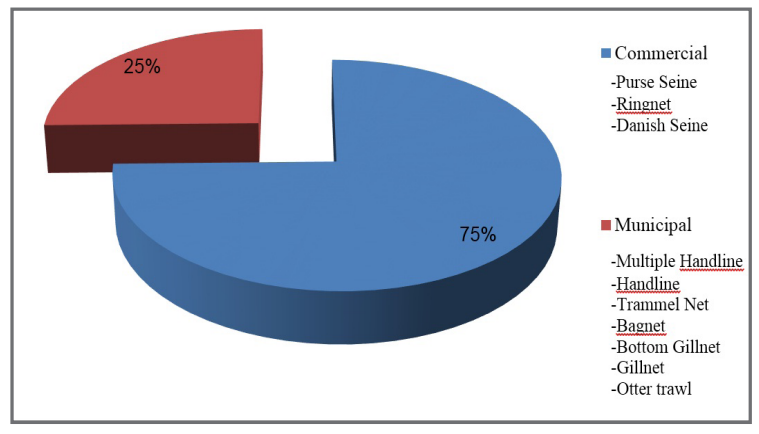

Figure 2. Percentage Share of Tuna Production in Municipal and Commercial Fisheries, 2003-2012

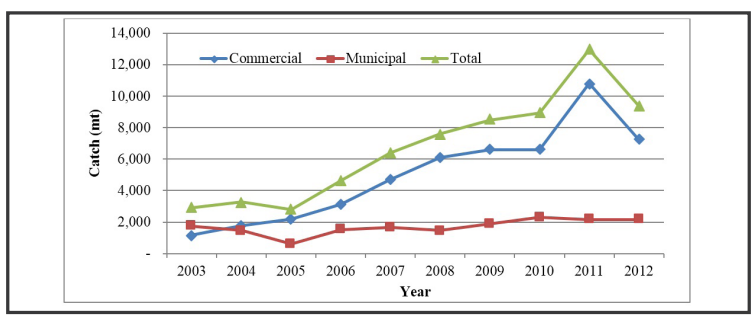

Figure 3. Annual Tuna Production (MT) in Zambales, 2003-2012 


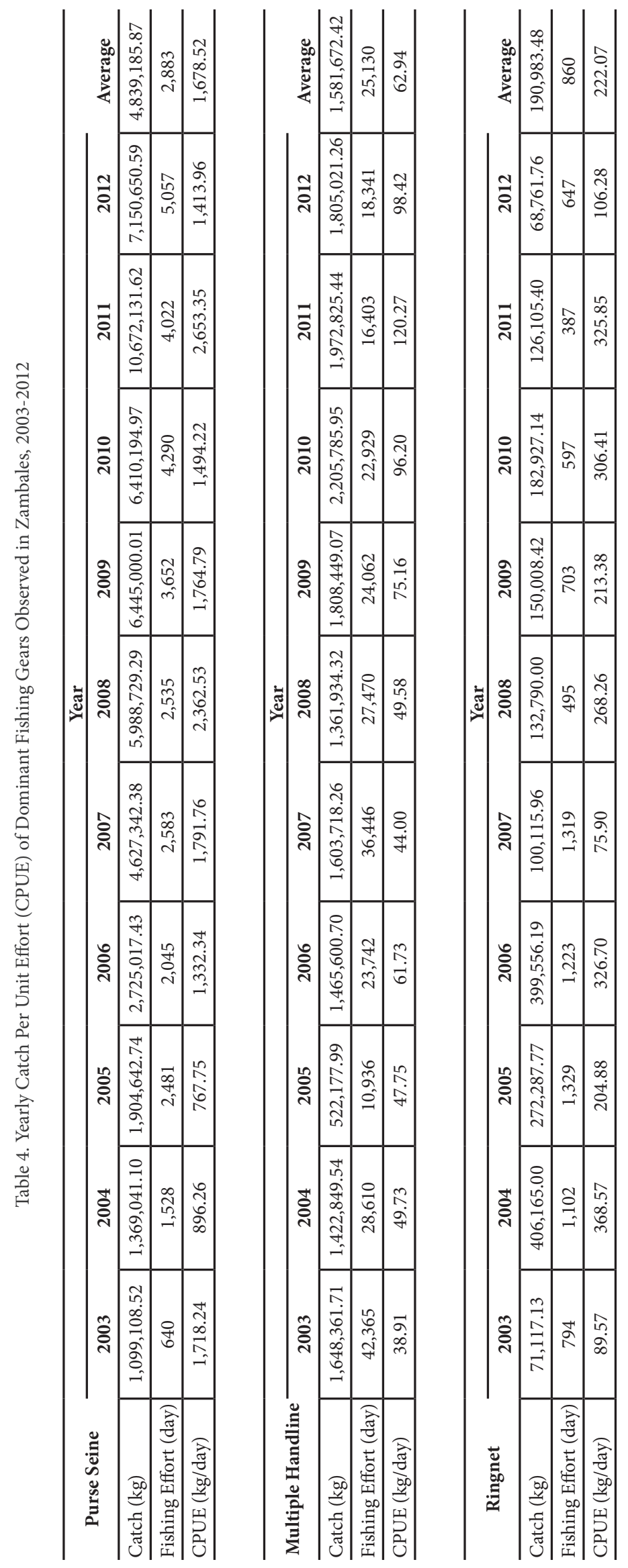




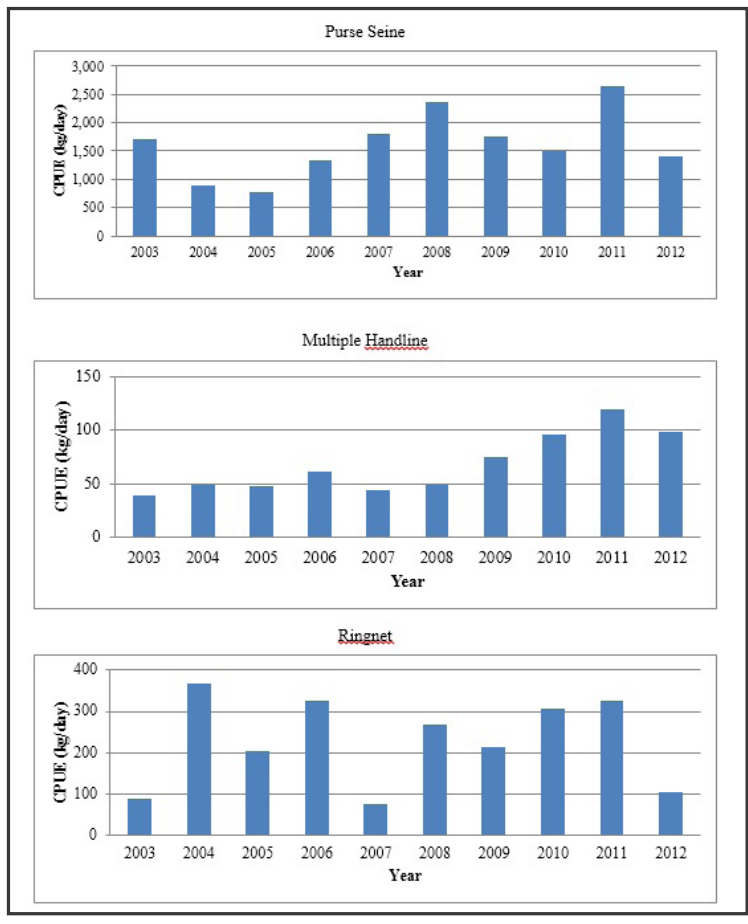

Figure 4. Trend in CPUE of Dominant Fishing Gears Observed in Zambales, 2003-2012

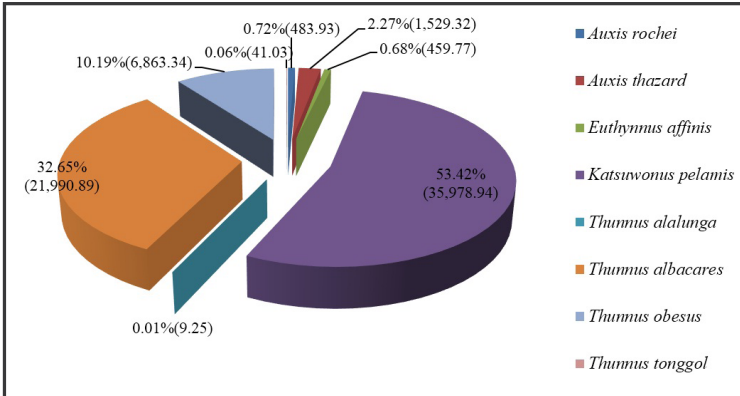

Figure 5. Catch Composition and Percentage Share of Tuna Species Landed in Zambales, 2003-2012

Tuna Project. The decrease in the catch for 2012 was due to the reduction in fishing activities because of bad weather caused by the frequent occurrence of typhoons in Zambales during that year.

\section{Catch Per Unit Effort (CPUE)}

Table 4 shows the catch per unit effort of the dominant fishing gears observed in the area for the tenyear period. Records show that purse seine, the most dominant commercial gear observed in the monitored landing sites, had an average CPUE of 1,678.52 kg/day, while for ring net, also a commercial gear, the computed CPUE was only $222.07 \mathrm{~kg} /$ day. For municipal fishing, multiple handline recorded an average catch of $62.94 \mathrm{~kg} /$ day.

The trend in the annual CPUE for the three dominant fishing gears showed a fluctuating trend both for commercial and municipal fisheries (Figure 4.) The highest CPUE obtained for purse seine and multiple handline was recorded on 2011.

\section{Catch Composition of Tuna Species Landed in Zambales}

Twenty-one species of tuna have been recorded in Philippine waters (BFAR \& WCPFC 2012). Eight of these species were caught in Zambales Coast. These were bullet tuna (Auxis rochei), frigate tuna (Auxis thazard), eastern little tuna (Euthynnus affinis), skipjack (Katsuwonus pelamis), albacore tuna (Thunnus alalunga), yellowfin tuna (Thunnus albacares), bigeye tuna (Thunnus obesus) and longtail tuna (Thunnus tonggol) (Froese and Pauly 2014).

Figure 5 illustrates the catch composition and percentage share in the catch of the different species of tuna landed in Zambales. The skipjack tuna (Katsuwonus pelamis) topped the list of the most dominant species with $35,978.94$ MT or $53.42 \%$ share followed by yellowfin tuna (Thunnus albacares) with $21,990.89$ MT or $32.65 \%$ share and bigeye tuna (Thunnus obesus) with 6,863.34 MT which contributes $10.19 \%$ share.

The catch composition varies depending on the type of gear being used for fishing. Figures 7 to 9 show the species composition of tuna landed catch by the three dominant fishing gears observed in Zambales.

Purse Seine recorded a total catch of $48,391.86$ MT, comprising of seven tuna species (Figure 6). Skipjack tuna (Katsuwonus pelamis) dominated the catch with 28,769.20 MT (61.18\%). Yellowfin tuna (Thunnus albacares) and Bigeye tuna (Thunnus obesus) ranked second and third in the catch composition of Purse Seine with a total catch of $13,759.80 \mathrm{MT}(26.36 \%)$ and 3,649.91 MT (7.76\%), respectively.

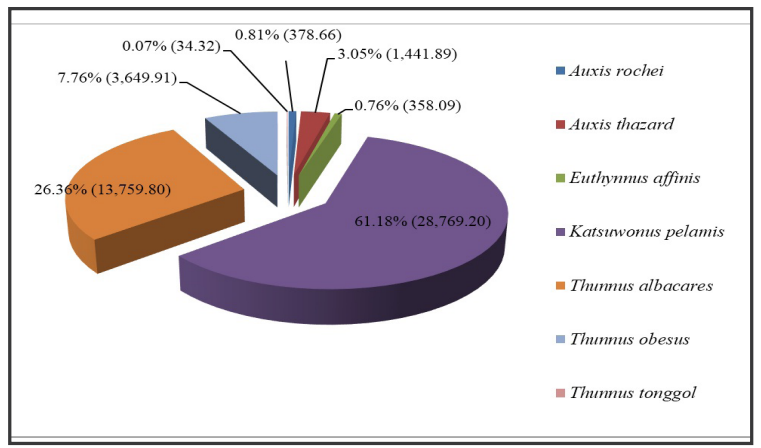

Figure 6. Species Composition of Landed Catch of Purse Seine in Zambales, 2003-2012

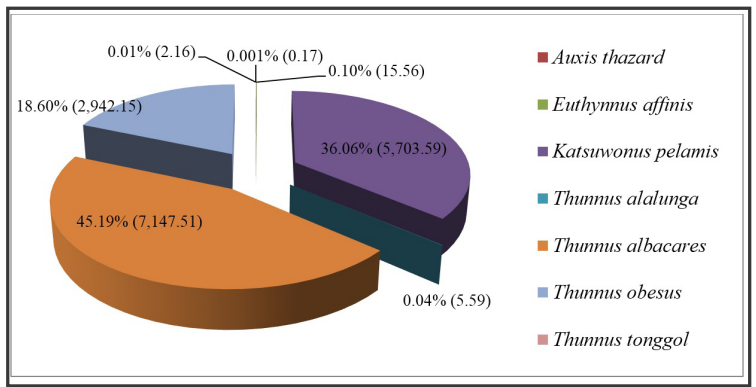

Figure 7. Species Composition of Landed Catch of Multiple Handline in Zambales, 2003-2012 
On 2011, the major tuna catches of purse seine landed in ports of various regions in the country are also the same with the result of study in Zambales, it is mainly composed of skipjack tuna with $40-55 \%$ share followed by yellowfin tuna with $12-37 \%$ share and other species with $20-40 \%$ contribution (BFAR \& WCPFC 2012)

In Figure 7, the recorded total catch of tuna species using Multiple Handline is 15,816.72 MT. Yellowfin, Skipjack, and Bigeye tuna dominated the catch but this time Yellowfin tuna ranked first with 7,147.51 MT followed by Skipjack tuna and Bigeye tuna with a total catch of 5,703.59 MT and 2,942.15 MT, respectively. A total of seven species of tuna were observed for this type of fishing gear.

Skipjack tuna and Yellowfin tuna comprised the biggest bulk of the catch of Ring Net (Figure 8) with 1,144.42 MT (59.92\%) and 423.01 MT (22.15\%), respectively. A total of $1,909.83$ MT of tuna catch composed of seven species was recorded using this type of fishing gear. Based on BFAR - Philippine Fisheries Observer Program Sampling activities for 2010 and 2011, the catch breakdown is as follows: skipjack tuna with 32$42 \%$ share and yellowfin tuna with $17-18 \%$ contribution on the total catch (BFAR \& WCPFC 2012). This shows that the tuna catch in ring net being landed in Zambales is similar to the result of the sampling activities in terms of species composition.

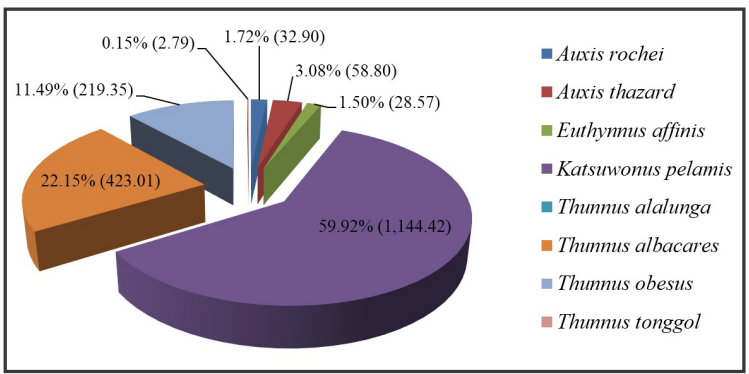

Figure 8. Species Composition of Landed Catch of Ring Net in Zambales, 2003-2012

\section{Seasonality of Dominant Tuna Species}

The monthly seasonal distribution of the three dominant tuna species being landed in Zambales during the period of study is shown in Figures 9 to 11 .

Production peak of Katsuwonus pelamis as shown in Figure 9 was recorded on the first quarter of the year and almost the same production volume for the succeeding quarters. In Figure 10, highest production of Thunnus albacares was observed on second and third quarters and nearly the same trend in the catch for other quarters. For Thunnus obesus, bulk of production appeared on first and second quarters of the year and observed to have almost consistent production on the remaining quarters (Figure 11).

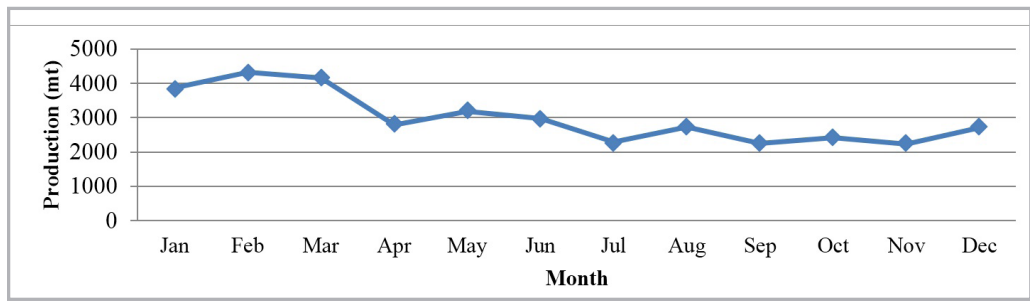

Figure 9. Seasonality of Katsuwonus pelamis, 2003-2012

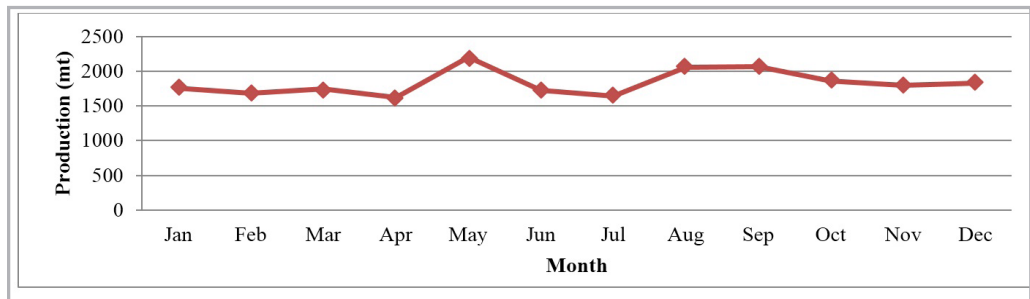

Figure 10. Seasonality of Thunnus albacares, 2003-2012

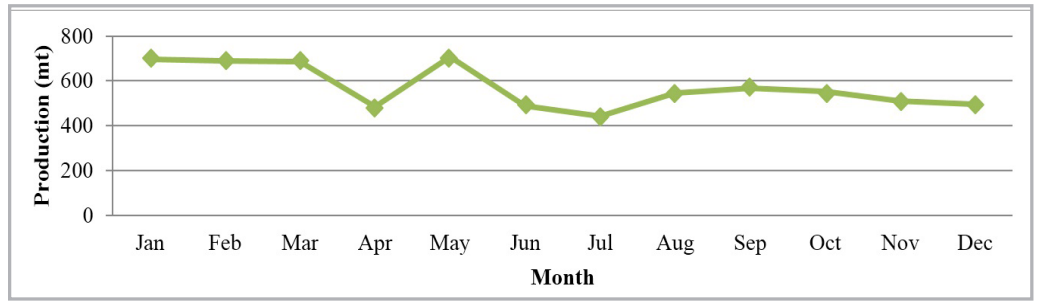

Figure 11. Seasonality of Thunnus obesus, 2003-2012 


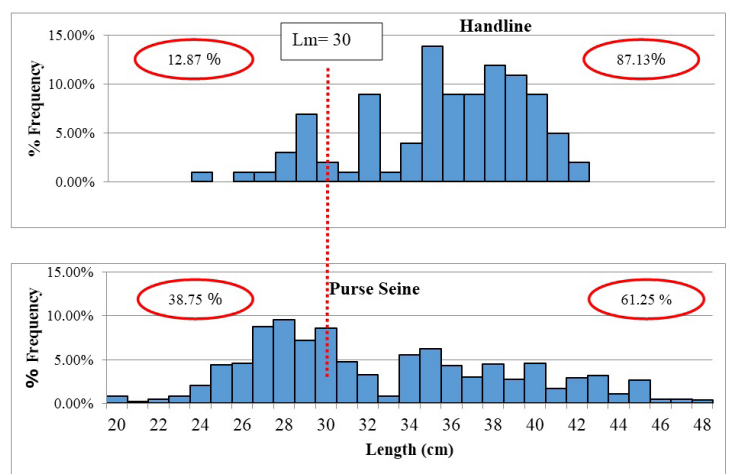

Figure 12. Size Composition of Auxis thazard Caught in Zambales, 2003-2012

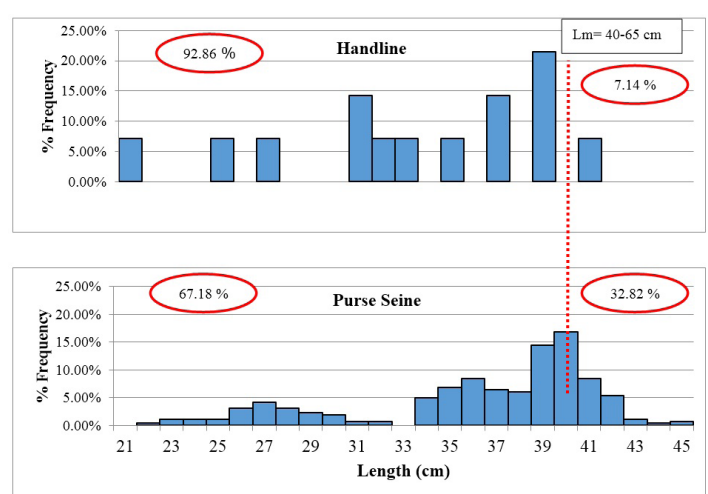

Figure 13. Size Composition of Euthynnus affinis Caught in Zambales, 2003-2012

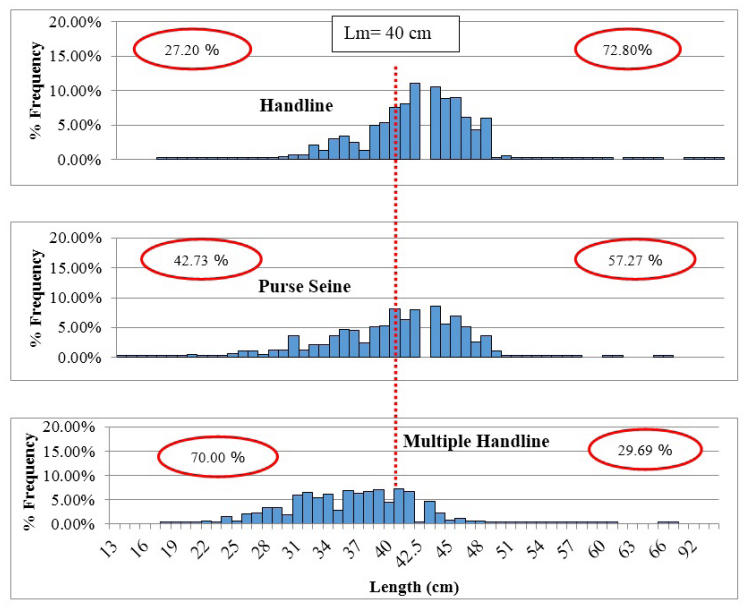

Figure 14. Size Composition of Katsuwonus pelamis Caught in Zambales, 2003-2012

Generally, there is a little seasonality in the tuna fisheries, other than influenced by monsoonal events and movements into and out of the area (BFAR 2012).

\section{Size Composition of Tuna Species Landed in Zambales}

Figure 12-16 shows the size composition of the dominant tuna species caught by major fishing gears in Zambales for the period of 2003-2012.

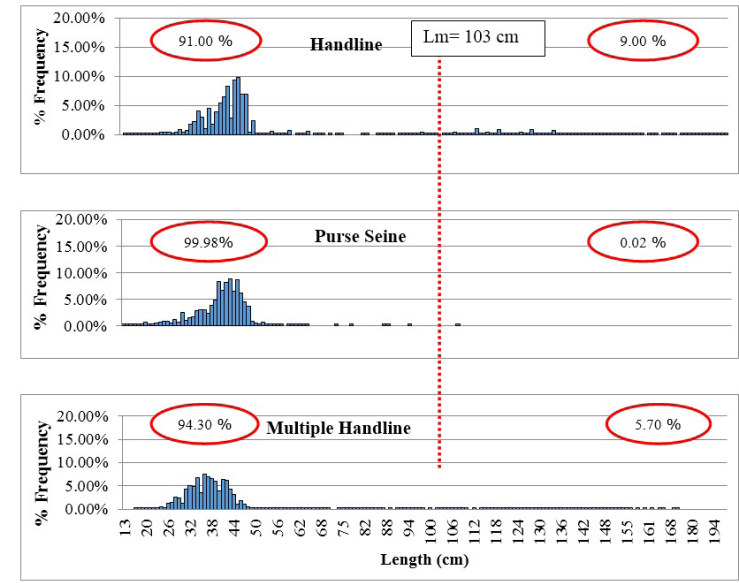

Figure 15. Size Composition of Thunnus albacares Caught in Zambales, 2003-2012

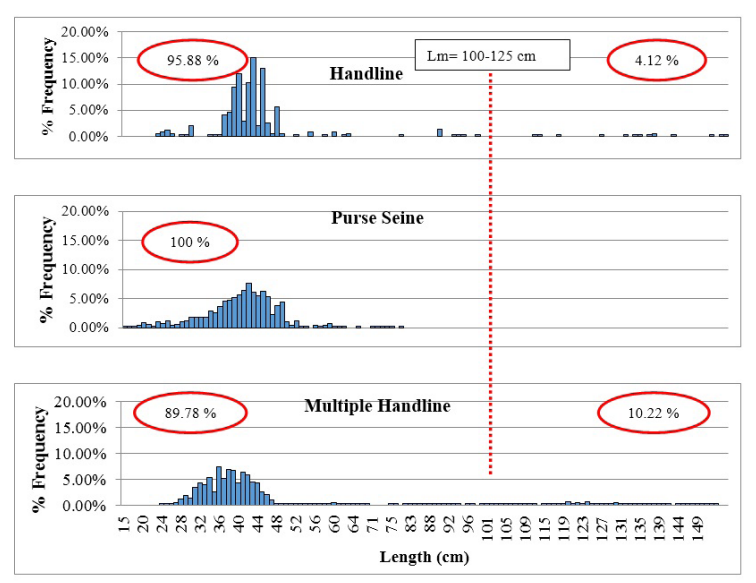

Figure 16. Size Composition of Thunnus obesus Caught in Zambales, 2003-2012

The size composition of Auxis thazard is presented in Figure 12. For handline fishing, $87.13 \%$ of the catch were above the length of maturity of $30 \mathrm{~cm}$ (Froese and Pauly 2014) while for purse seine, only $61.25 \%$ of this species were caught above the length of maturity.

As shown in Figure 13, the length of maturity for Euthynnus affinis ranges from 40-65 cm (Froese and Pauly 2014). Record shows that this species was usually caught in Zambales Coast below length of maturity both for handline and purse seine . Ninety three percent of the handline catch and $67.18 \%$ of the purse seine catch were below the length of maturity of this species.

The length of maturity for Katsuwonus pelamis is $40 \mathrm{~cm}$ as can be seen in Figure 14 (Froese and Pauly 2014). Based on the record, $72.80 \%$ of the handline catch and $57.27 \%$ of the purse seine catch for this species had sizes above the length of maturity. For multiple handline, only $29.69 \%$ of the catch was composed of mature skipjack tunas thus, $70 \%$ were composed of small skipjack tuna.

Figure 15 illustrates the size composition of Thunnus albacares caught in Zambales for the 10-year study period. The length of maturity for this species is $103 \mathrm{~cm}$ (Froese and Pauly 2014). Based on the gathered 
data, more than $90 \%$ of this species were caught in the area before they reach their maturity. Results on length frequency were almost the same using the three types of fishing gears observed in the area- purse seine, handline and multiple handline. Among these gears, purse seine recorded the highest percentage of small yellowfin tuna catch.

The size composition of Thunnus obesus is shown in Figure 16. Majority of the sizes being caught by purse seine, handline and multiple handline for this particular species were below the length of maturity of $100 \mathrm{~cm}$ (Froese and Pauly 2014). As observed, all of the bigeye tuna catch of purse seine were below the length of maturity.

Based on the figures presented, most of the tuna species being caught in Zambales were small tunas. Yellowfin, bigeye, and skipjack tuna spawn extensively in the Philippine waters, and juvenile tunas make up a high proportion of the tuna catch of all species (BFAR 2012).

\section{SUMMARY}

There were ten types of tuna fishing gears observed in Zambales, seven types for municipal fishing and three types of gears for commercial fishing. The most dominant tuna fishing gear is the purse seine, followed by multiple handline and ringnet.

The tuna catch in Zambales showed an increasing trend from 2005 to 2011, highest production was recorded on 2011 with 12,968 MT. Increase in the catch can be attributed to the addition of two landing centers in Sta. Cruz, Zambales as sampling stations and unloading of catches of other fishing vessels from nearby provinces. The decrease in the catch for 2012 was due to the reduction in fishing activities because of bad weather caused by the frequent occurrence of typhoons in Zambales during that year.

The catch per unit effort was also computed. Results showed that purse seine, which is a commercial fishing gear, has the highest average CPUE with $1,678.52 \% \mathrm{~kg} /$ day, followed by ring net with $222.07 \mathrm{~kg} /$ day, and multiple handline, which is a municipal fishing gear, with $62.94 \mathrm{~kg} /$ day. The annual CPUE for the three dominant fishing gears showed a fluctuating trend both for commercial and municipal fisheries.

For catch composition, the most dominant species caught is the skipjack tuna (Katsuwonus pelamis) followed by yellowfin tuna (Thunnus albacares), and bigeye tuna (Thunnus obesus).
The monthly seasonal distribution of the three dominant tuna species being landed in Zambales during the period of study was also assessed. Peak in the catch of Katsuwonus pelamis was recorded in the first quarter of the year. For Thunnus albacares, the highest catch was observed on second and third quarters. The bulk of catch for Thunnus obesus appeared also on first and second quarters of the year. All of these species were observed to have almost consistent catch for the remaining quarters of every year.

The size composition of the seven tuna species for the period of 2003-2012 varies per species. Records show that most of the tuna species landed in Zambales were caught before they reach the length of maturity. Among those species, T. albacares and T.obesus recorded the highest percentage of small tuna catch.

\section{RE F ER E N C ES}

Barut N. 2002. National Tuna Fishery Report-Philippines. Working paper during the 15th Meeting of the Standing Committee on Tuna and Billfish, Honolulu, Hawaii.

BAS. 2003-2012. Fisheries Statistics of the Philippines. Bureau of Agricultural Statistics. Quezon City, Philippines.

BFAR. 2012. National Tuna Management Plan of the Philippines.

BFAR and WCPFC. 2012. Philippine Tuna Fisheries Profile. West Pacific East Asia Oceanic Fisheries management Project (WPEA OFMP); [accessed 2014 October].https://www.wcpfc.int/doc/tfp-201211/philippine-tuna-fisheries-profile

Froese R, Pauly D. editors. 2014. Fishbase; [accessed 2014 October]. http://www.fishbase.org.

Ganaden SR, Lavapie-Gonzales F. 1999. Common and Local Names of Marine Fishes of the Philippines. Bureau of Fisheries and Aquatic Resources, Philippines. p. 385.

Vera CA. 2007. Tuna Industry: Tonnes of Tuna. SAMUDRA Report No. 46. Philippines. p. 15; [accessed 2014 October]. http://community.icsf.net/ en/samudra/detail/EN/2924-Tonnes-of-tuna.html 


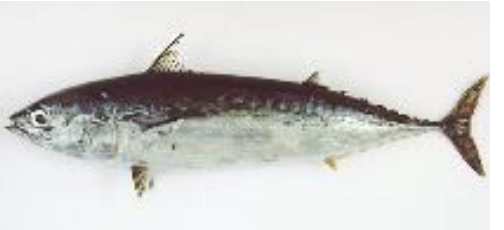

Species: Auxis rochei English Name: Bullet Tuna Local Name: Bonito/Piyok

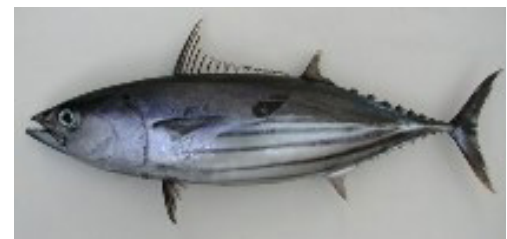

Species: Katsuwonus pelamis English Name: Skipjack Tuna Local Name: Gulyasan (Ganaden 1999)

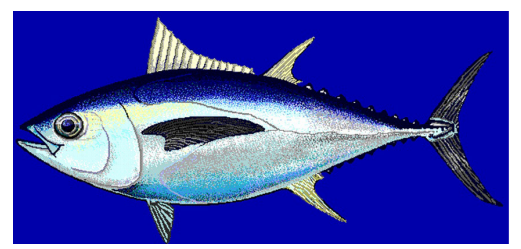

Species: Thunnus obesus English Name: Bigeye Tuna Local Name: Tambakol (Ganaden 1999)

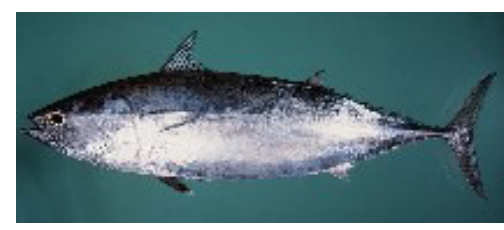

Species: Auxis thazard English Name: Frigate Tuna Local Name: Tulingan (Ganaden 1999)

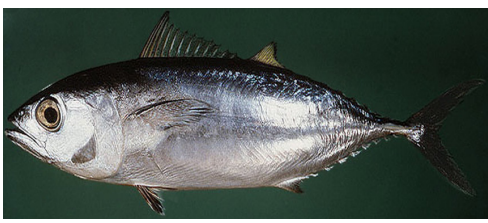

Species: Thunnus albacares English Name: Yellowfin Tuna Local Name: Tambakol (Ganaden 1999)

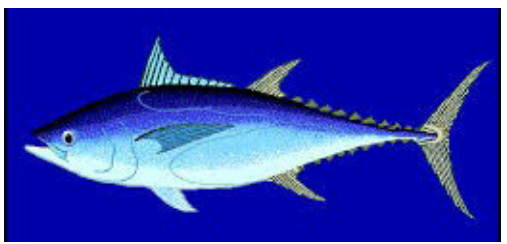

Species: Thunnus tonggol

English Name: Longtail Tuna

Local Name: Tambakol/Bonito (Ganaden 1999)

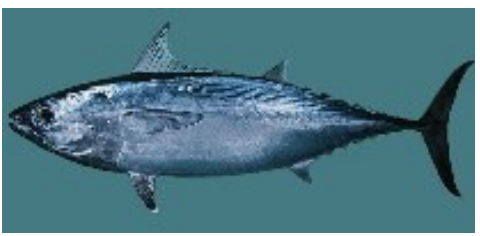

Species: Euthynnus affinis

English Name: Eastern Little Tuna/ Kawakawa

Local Name: Tulingan (Ganaden 1999)

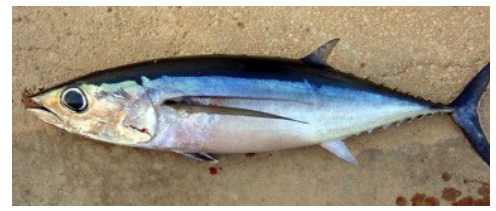

Species: Thunnus alalunga

English Name: Albacore Local Name: Tambakol/Bonito 